Research in plant pathology covers a wide field. Progress has been made in devising staining methods for preparations of plant viruses for electron miero. scopy at high resolution. This is new work, but enough progress has been made to encourage the hope that the methods will contribute usefully to the further elucidation of particle structure. The increasing importance of cereal viruses in agriculture adds to their interest, and useful information on infectivity and host ranges has been obtained. Experiments on initial field establishment of potato blight (Phytophthora infestans) have shown that this may occur without the normal stem-infecting stage. It is likely, however, that infection from contaminated soil can only occur in a wet season such as 1958. Trials on the susceptibility to wilt (Fusarium oxysporum f. pisi) of pea varieties commonly grown in Britain have shown that resistance exists, but the parasite itself is so variable that the breeding of resistant varieties will not be easy.

The Nematology Department has conducted studies on the changes in eelworm populations under different rotations and individual crops. These together with concurrent observations on the movement of eelworms in soil and over plants should interest those concerned with the control of these pests in the field. Frit flies, gall midges, wheat bulb fly, slugs and earthworms are included in the wide range of animals studied by the Entomology Department. A short section deals with the ecology of the natural enemies of aphids. The Bee Department, as a result of improved methods of assay, has learned more of the nature and function of 'queen substance' produced in the mandibular glands of queen honey bees. It has been shown that 'queen substance' contains an inhibitor which, when fed to queen honey bees, can prevent them from queen rearing and which can also inhibit ovary development in queenless worker honey bees.

As a result of the disastrous epidemic of virus vellows of sugar beet in 1957, the staff of the Dunholme Field Station organized a survey of crops and issued spray warnings when needed. As a result, 100,000 acres were sprayed with very satisfactory results when compared with unsprayed areas in September. The value of spraying against aphids to check the spread of virus yellows is now firmly established.

This account has necessarily omitted much worthy of mention, but it is impossible, in a short review, to do justice to all the work described in this report and the selection of items for particular mention here is obviously open to criticism. The extremely useful list of publications for the year 1958, each with an abstract of the contents, with which the report closes, is a fitting indication of the value of Rothamsted to biology and agriculture alike. J. H. WESTERN

\title{
AUSTRALIAN DEFENCE STANDARDS LABORATORIES REPORT, 1957
}

$\mathrm{T}$ HE main sections of the annual report of the Australian Defence Standards Laboratories for the year ended June 30, 1957 (Pp. iv +60 . Maribyrnong, Victoria: Defence Standards Laboratories, Department of Supply, 1959), are devoted to a statement of the functions of, and scope of work undertaken by, the Laboratories and deseriptions of some of the more important projects and investigations carried out by the Divisions of Chemistry, Metallurgy and Physics.

In the Metallurgy Division work has continued on the production and investigation of chromiumbase high-temperature alloys. The ultimate aim is to develop alloys suitable for use in gas turbines operating at rotor blade temperatures of $950^{\circ} \mathrm{C}$. or higher. The plant for the production of pure chromium has operated satisfactorily and a total of $475 \mathrm{lb}$. of metal was produced during the year. It has been shown that ductile chromium can be made from suitably pure electrolytic chromium. Investigations included experiments on the tensile properties of annealed chromium, the influence of pre-strain on ductility, precipitation hardening effects and creep behaviour. A fractographic study, augmented by $\mathrm{X}$-ray diffraction tests, was made of the cleavage surfaces in cast chromium. In addition, work has been done on titanium alloys; cathodic protection of ships and naval structures; and the mechanism of polishing and the nature of mechanically polished metal surfaces.

The activities of the Physics Division are discussed under the headings of chemical physies; radiological physics; the development and testing of electrical and electronic components for use by the armed services; and metrology. The study by the micro- wave interferometric technique of the propagation of detonation has been most fruitful. Radiation alarm systems and other safeguards against the mishandling of radioactive sources have been developed and work has continued on the determination of the energy and angular distributions of the radiation intensity in air at various distances from a point radioactive source. Facilities for the precise calibration of end standards of length have been improved, and standardizations of lengths up to 40 in. based on the wave-length of light can now be made. A technique has been developed for determining the mean diameters of eapillary tubes by the mercury content method to an accuracy of 0.00004 in.

The Chemistry Division has been active in a variety of fields, including the determination of gases in metals and alloys; the microdetermination of silicon; infra-red spectroscopy; adsorption; and organic and polymer chemistry.

The annual report lists the various personnel of the Laboratories and their status, and gives details of the publications by members of the staff during the year under review. Papers were presented by members of the staff to the thirty-second meeting of the Australian and New Zealand Association for the Advancement of Science held at Dunedin during January 1957 and to the Institute of Physics Conference on Contemporary Opties in Sydney during September 1956. Noteworthy visitors to the Laboratories during the year were Sir Owen WansbroughJones, ehief scientist of the British Ministry of Supply, and Sir Leslie Martin, chairman of the Australian Defence Research and Development Policy Committee. 